\title{
Management of Character Education at Al-Fityan Integrated Islamic Elementary School, Gowa and Al-Biruni Mandiri Makassar Integrated Islamic Elementary School: A Multi-Case Study
}

\author{
Salim Hasan; Abdul Rahman; Andi Bunyamin; Hasibuddin \\ Universitas Muslim Indonesia (UMI) Makassar, Indonesia \\ http://dx.doi.org/10.18415/ijmmu.v8i7.2891
}

\begin{abstract}
This study aims to determine, study and analyze character education management and its effectiveness at SDIT Al-Fityan School Gowa and SDIT Al-Biruni Mandiri Makassar. This research is a qualitative research with a phenomenological approach. The method of collecting data is through interviews with school principals, vice principals for curriculum affairs, students, homerooms and teachers. Other data sources are through observation and documentation. The data obtained were analyzed by data reduction steps, data presentation and conclusion drawing. The results of this study indicate that character education planning begins with establishing the school's vision, mission, goals and programs, as well as determining character values, designing a curriculum that integrates character values into an integrated syllabus and lesson plans based on Islamic education. The organization of character education is carried out by the principal through coordination between elements, division of tasks based on SOPs, controlling and evaluating. implementation. Implementation of character education through (1) integrating character values into Islamic values-based learning, (2) through apperception activities or morning briefings, (3) mentoring activities or Islamic Personal Development, (4) Al-Qur'an mentoring, outing class and outbound. Character education is also carried out through extracurricular activities, habituation of worship and Islamic etiquette, modeling and school culture. Supervision of character education from the principal, and homeroom supervision of students through mutaba'ah/scoring boards. The implementation of character education has formed students who are able to be religious, able to apply Islamic etiquette, very good in tolerance, speak politely, independently, help, socially care, honest, disciplined, confident, cooperative and responsible.
\end{abstract}

Keywords: Management; Character; Integrated Islamic School

\section{Introduction}

The state and government pay great attention to character education in educational institutions. This is important because educational institutions are the second educational environment after the family environment. The pedagogic function in the family cannot be carried out optimally because the family also has other functions which are also very important in maintaining the continuity of the family. 
Not all things concerning children's education, especially character, moral and ethical education can be done in the family environment by parents. Therefore, educational institutions play a very important role in instilling character values either through the learning process in the school environment either in class or extra activities outside the classroom (Jambak, 2017; Hulawa, 2018; Aprilia et al., 2021).

Strengthening character education today is very relevant to overcome the moral crisis that is happening before us. The moral crisis that is currently happening is very worrying in society which involves what is most valuable to parents, namely children, both for children at all levels from school to college (DeRoche \& Williams, 2001; Satria \& Shahbana, 2020). Violence between students or students, persecution, murder, rape, theft and free sex, we can see in the mass media everyday.

The development of science and technology without boundaries can have positive and negative impacts. The positive impact is the more open and spread of information and knowledge from and to all over the world. The negative impact is the occurrence of changes in behavior, ethics, norms, rules or morals of life that are contrary to the ethics, norms, rules and morals of life that exist in society (Jamun, 2018). As an example, the BKKBN in 2013 stated that 20.9 percent of adolescents in Indonesia experienced pregnancy before marriage. Meanwhile, the results of the BPS survey in 2012 revealed that the teenage pregnancy rate between 15-19 years old was 48 percent out of 1000 pregnancies (Magdalena \& Notobroto, 2016).

The facts above show that the expectations of the state and government as reflected in the laws and government regulations in their implementation are still far from expectations. The desire of the state and government in realizing students with character through educational institutions has not been fully successful. This is also exacerbated by the very minimal portion of religious education in public schools (Nata, 2017; Baharun \& Ummah, 2018).

To form and develop character education for students in schools requires cooperation from all parties, including support from the government through the education office, schools, teachers, students, parents and the community. To implement this cooperation, a good education management is needed. Educational management is the entire process of directing and integrating everything personal, spiritual and material related to the achievement of educational goals (Education, 2007).

Wibowo (2017) said that in order for the implementation of character education in schools to be effective and efficient, the most appropriate solution is to implement character education management. Effective management of character education in schools is important so that all components of education in schools can synergistically support the application of character education. Through effective character education management,especially with communication management, there will be synergistic cooperation between the government, school administrators, school committees, the community and parents of students (Wibowo, 2017). The management of character education in schools is internalized through management functions, namely planning, organizing, implementing and supervising (Thompson et al., 2020). That is, how character education is planned, how is it organized, how is it implemented and how is it supervised.

From the description above, it can be concluded that with the current condition of the nation and the younger generation as described above, a good educational process with effective and efficient management is needed in developing and instilling character values or noble character through educational institutions. One of the educational institutions that is currently receiving a lot of attention and interest, especially from the upper middle class, is the Integrated Islamic School (SIS).

The establishment of an integrated Islamic school is seen as a modernization of Islamic educational institutions in Indonesia, namely combining the pesantren education system with education in 
public schools. This is the main attraction for middle and upper class Muslims to send their children to these schools.

The magnitude of the attractiveness of the Muslim community, especially from the upper middle class because of the advantages possessed by the Integrated Islamic School (SIS), the authors are interested in further research related to education management in integrated Islamic schools, especially related to character building at Integrated Islamic Elementary Schools SDIT) Al-Fityan School Gowa and Integrated Islamic School (SDIT) Al-Biruni Mandiri Makassar.

Al-Fityan Integrated Islamic Elementary School was inaugurated by the Kuwaiti Ambassador to Indonesia Faisal Sulaiman Al-Musaileem on June 13, 2009, together with the Governor of South Sulawesi and the Regent of Gowa Regency.

Integrated Islamic Elementary School Al-Fityan School is one of the largest private elementary schools in Gowa district in terms of building facilities, educational infrastructure, teaching and educational staff and the number of enthusiasts. Currently, Al Fityan Integrated Islamic Elementary School has 653 students, a large number for a private school. In addition, students of the Al-Fityan School integrated Islamic Elementary School have also won various achievements in sports competitions, Mathematics Olympiads, Science, Tahfizul Qur'an and others both at the regional and national levels. This shows the success of the coaching carried out by the school management.

Likewise with the Al-Biruni Mandiri Integrated Islamic Elementary School. This school was founded and operated in 2002. The name Al-Biruni is taken from the name of a Muslim scientist named Abu Raihan Al-Biruni (975 - 1048 AD). Al-Biruni is a scientist who mastered various branches of science, including history, physics, mathematics, astronomy, linguistics, comparative religion and earth sciences. This scientific thought then inspired the establishment of the Al-Biruni Mandiri Integrated Islamic School, with the hope that this school will later produce Muslim individuals with strong characters and able to contribute to the world.

Currently, Al-Biruni Mandiri Integrated Islamic Elementary School has its own school building located in two different locations, namely on Jalan Jipang Raya and on Jalan Quarantine Makassar with complete learning facilities. Currently the integrated Islamic Elementary School Al-Biruni Mandiri is fostering more than 300 students. Among the missions carried out by this school is to implement the AlQur'an learning process by prioritizing a quality-based system to support the formation of students with character, tartil and tahfiz Al-Qur'an. 'an.

This study aims to determine the management of character education at the Integrated Islamic Elementary School (SDIT) Al-Fityan School Gowa and the Integrated Islamic Elementary School (SDIT) Al-Biruni Mandiri Makassar and the effectiveness of character education at the Integrated Islamic Elementary School (SDIT) Al-Fityan Regency. Gowa and the Al-Biruni Mandiri Integrated Islamic Elementary School (SDIT) Makassar.

\section{Research Methods}

This study aims to determine, examine and analyze character education management and its effectiveness at SDIT Al-Fityan School Gowa and SDIT Al-Biruni Mandiri Makassar. This research is a qualitative research with a phenomenological approach. The method of collecting data is through interviews with school principals, vice principals for curriculum affairs, students, homerooms and teachers. Other data sources are through observation and documentation. The data obtained were analyzed by data reduction steps, data presentation and drawing conclusions. 


\section{Results and Discussion}

\section{Management of Character Education at SDIT Al-Fityan Shool Gowa and SDIT Al-Biruni Mandiri Makassar}

\section{a) Character Education Planning}

The planning of character education in the two schools has the same planning through annual meetings to establish systems, starting from the vision, mission, goals and programs to their application in the field, including formulating character values and internalization steps in school programs. The character values developed in the two schools are also a combination of characters based on the ministry of education and distinctive characters based on Islamic morals.

Character Value Comparison Table

\begin{tabular}{|c|c|c|}
\hline $\begin{array}{l}\text { Character Value of } \\
\text { Kemendiknas }\end{array}$ & $\begin{array}{l}\text { SDIT Character Value } \\
\text { Al-fityan School } \\
\end{array}$ & $\begin{array}{l}\text { SDIT Al-Biruni Mandiri Character } \\
\text { Value }\end{array}$ \\
\hline 1. Religious & 1. Love God with all & 1. Obedience to worship \\
\hline 2. Be honest & His creations & 2. Behave gratitude (gratitude) \\
\hline 3. Tolerance & 2. Independent, & 3. Tolerance when hanging out \\
\hline 4. Discipline & disciplined and & (tolerance) \\
\hline 5. Hard work & answerable & 4. Pray before and after doing activities \\
\hline 6. Creative & 3. Be honest, & (religious). \\
\hline 7. Independent & trustworthy and & 5. Honesty (honesty) \\
\hline 8. Democratic & speak wisely & 6. Discipline \\
\hline 9. Curiosity & 4. Respectful, polite & 7. Responsible (trust) \\
\hline 10. National spirit & and good listeners & 8. Speak polite words (polite) \\
\hline 11. Love of the motherland & 5. Generous, helpful & 9. Caring \\
\hline 12. Appreciate achievements & and cooperative & 10.Cooperation \\
\hline $\begin{array}{l}\text { 13. Friendly / communicative } \\
\text { 14 Dmai Tane }\end{array}$ & 6. Confident, creative & 11.Confidence (confidence) \\
\hline 15. Likes to read & 7. Good and fair leader & \\
\hline 16. Cares for the environment & 8. Kind and humble & \\
\hline 17. Social care & 9. Tolerance, love & \\
\hline 18. Res & cy & \\
\hline
\end{tabular}

From the table above, it can be seen that there are a number of character values from the ministry of education that are accommodated at SDIT Al-Fityan School Gowa and SDIT Al-Biruni Mandiri although with slightly different language, namely Religious, honest, disciplined, tolerant, responsible and caring. The rest are character values based on the characteristics of each school. In addition, in planning for character education, an integrated curriculum is formulated that integrates character values and Islamic teachings in the fabric of the curriculum and syllabus which is then outlined in an integrated learning implementation plan (RPP). Another characteristic of character education planning in integrated Islamic schools is the arrangement of school and classroom environments with character by installing billboards, posters and calligraphy engravings of the Qur'an and Hadith, containing messages related to Islamic morality.

The integration of Islamic teachings in the curriculum and the arrangement of the school environment with Islamic-inspired ornaments is part of the definition of an integrated Islamic school itself. As explained earlier on the theoretical basis that an integrated Islamic school is essentially a school that implements the concept of Islamic education based on the Qur'an and As-Sunnah. The operational 
concept of an integrated Islamic school is the concept of civilizing, inheriting and developing Islamic teachings, Islamic culture and civilization from generation to generation.

From the concept of character education management planning at SDIT Al-Fityan School Gowa and SDIT Al-Biruni Mandiri Makassar stated above is in accordance with the meaning contained in the planning itself. Planning is an activity related to efforts to formulate a program which includes everything that will be carried out, determination of goals, policies, directions to be taken, procedures and methods to be followed in an effort to achieve goals (Saefullah, 2019).

\section{b) Organization of Character Education}

The organization of character education at SDIT Al-Fityan School Gowa and SDIT Biruni Mandiri Makassar is based on the school's organizational structure. The implementation of character education is directly coordinated by the principal with the deputy principal, tiered up to the person in charge of the program, or the program coordinator, homeroom teacher and teacher. It can be seen that there is a difference between school organization at SDIT Al-Fityan School Gowa and SDIT Al-Biruni Mandiri Makassar. SDIT Al-Fityan Gowa has a very large number of students, so the school's organizational structure is larger. Under the principal there is a deputy principal, program person in charge (PJ), level (class) coordinator, homeroom teacher and teachers.

The results of the above research are in accordance with organizational theory in educational management, namely the process of connecting people involved in educational organizations, integrating tasks and functions in a network system that has a relationship with one another (Saefullah, 2019). With this understanding, organizing is to unite all elements in the organization and organize and link the work in the system that is required to be effective and efficient.

\section{c) Implementation of Character Education}

A. The implementation of character education at SDIT Al-Fityan School Gowa is carried out through direct and indirect learning. Indirect learning is through the installation of religious messages in the school and classroom environment, while direct learning is carried out by integrating character values into Islamic education-based learning, doing apperception or character strengthening before the teaching and learning process begins with morning remembrance and dhuha prayer. Learning uses varied methods with the Contextual Teaching and Learning (CTL) learning model. Direct learning outside the classroom through outing class and out bound activities. Internalization of character values is also carried out through a variety of extracurricular activities, habituation of worship, Islamic etiquette, social manners, habituation of patience and discipline, exemplary and enforcement of discipline through clear and firm rules. Supervision of character education is based on the responsibilities in a structured manner from the principal, vice principal, program manager, homeroom teacher and teachers. Supervision is also carried out through coordination meetings, and homeroom supervision of students at school until they get home through the mutaba'ah control book.

B. Hasib et al. (2017) suggest that character education needs to be embedded with local wisdom or the community upholdingvalues. Implementation of character education at SDIT Al-Biruni Mandiri Makassar through character strengthening in morning briefing activities, integrating character values into Islamic education-based learning, character strengthening through Islamic personal development activities, faith and piety building nights, outing class and out bound activities, the use of methods teaching that varies with the Contextual Teaching and Learning (CTL) learning model. Character values are also instilled through various extracurricular activities, habituation of worship, Islamic etiquette, habituation of order and discipline, exemplary and enforcement of discipline through school culture. Supervision of character education is carried out externally through supervision from the education office,

Management of Character Education at Al-Fityan Integrated Islamic Elementary School, Gowa and Al-Biruni Mandiri Makassar Integrated Islamic Elementary School: A Multi-Case Study 
internally supervision is carried out by the principal and deputy principal, supervision of homeroom teachers / homeroom assistants to students through scoring boards, and supervision through coordination meetings.

\section{d) Supervision of Character Education}

The supervision of character education at SDIT Al-Fityan Gowa is externally carried out by the Gowa education office in the form of supervision of teachers. Internally supervision is carried out based on: 1) the level of responsibility from the principal, vice principal, program manager (PJ), level coordinator to homeroom teachers and teachers; 2) homeroom supervision through mutaba'ah on student activities at home; 3) internal supervision through annual coordination meetings, semester, quarterly evaluations, homeroom meetings and teacher council meetings.

Supervision of character education at SDIT Al-Biruni Mandiri Makassar through external supervision from the Makassar city education office in the form of supervision of teacher performance. While internally supervision is carried out in stages based on responsibilities within the organization, principals, vice principals, homerooms \& homeroom assistants, and subject teachers, tahfiz coordinators. In addition, supervision is carried out by the homeroom teacher / homeroom assistant on the activities of students at home through a scoring board. Internal supervision is also carried out through annual coordination meetings, semester, quarterly evaluations, homeroom meetings and teacher council meetings.

The results of the above study indicate that the supervision carried out in both schools is in accordance with management theory that one form of supervision is top-down supervision, namely supervision carried out by direct superiors to subordinates. In this case, supervision is carried out by the principal and deputy principal, then how long is the person in charge of the field either through direct observation or through meetings with teachers, and supervision of homeroom teachers towards students both at school and at home.

\section{Effectiveness of Character Education at SDIT Al-Fityan School Gowa and SDIT Al-Biruni Mandiri Makassar Maka}

From the report cards of students' learning outcomes at SDIT Al-Fityan School Gowa based on report cards for class V Ikhwan and V Akhwat it can be concluded that character education in this school is effective. This can be seen from the learning outcomes on aspects of spiritual and social attitudes, namely students have been able to apply the character accustomed to saying thoiyybah sentences (alhamdulillah, subahanallah, masya Allah, Innalillahi wainna ilaihi rajiun and the like), students are able to practice eating and eating etiquette. drinking, being able to apply words of apology, asking for help, thanking, and being able to help parents at home, being respectful and polite to older people, and knowing the law of having to cover aurat. The study conducted by Baguna, I. (2020) suggests the same results that the implementation of character education in school has positive impact through changes in discipline and productivity.

Character education at SDIT Al-Biruni Mandiri Makassar is also effective. From the report cards of learning outcomes for grades V and VI, it can be seen that all students have very good spiritual attitudes in worship obedience, behave in gratitude, tolerance when socializing, pray before and after doing work. While the social attitudes of all participants were very good in honesty, discipline, responsibility, polite speech, caring, cooperation and self-confidence. 


\section{Conclusion}

Management of character education at SDIT Al-Fityan School Gowa and SDIT Al-Biruni Mandiri Makassar is carried out through planning, organizing, implementing and monitoring. Character education planning is carefully designed through setting the vision, mission, goals, and designing an integrated curriculum based on Islamic education, as well as designing a school environment to support character building. The organization of character education is coordinated. by the principal with the division of tasks and responsibilities, controlling and evaluating its implementation. The implementation of character education at SDIT Al-Fityan School Gowa and Al-Biruni Mandiri Makassar has some similarities in addition to small differences. The basic similarities are found in classroom learning in integrating character values in Islamic teaching-based learning, which is sourced from the Qur'an, Hadith and stories using various learning methods with Contextual Teaching and Learning (CTL) learning methods. Learning outside the classroom through outing class and out bound activities. Other similarities are Al-Qur'an education (tahsin and tahfiz) and Islamic teaching-based character education in the Islamic mentoring program at SDIT Al-Fityan School Gowa and Islamic Personal Development (BIP) at SDIT Al-Biruni Mandiri Makassar. internalization of character values is carried out through a variety of extracurricular activities, habituation of worship and Islamic etiquette, giving examples, enforcing discipline through school rules and culture. Supervision of character education is carried out by school principals, deputy principals and program managers, homeroom supervision of students through mutaba'ah/scoring boards, as well as supervision through coordination meetings.

The implementation of character education at SDIT Al-Fityan School Gowa and SDIT Al-Biruni Mandiri Makassar is effective in instilling characters accustomed to saying thaiyyibah sentences, being able to apply characters accustomed to practicing eating and drinking etiquette, being able to apply the words sorry, please and thank you, helping parents at home, know the law must cover the genitals. Students are very good in worship obedience, behave in gratitude, tolerance, pray before and after carrying out activities, honesty, discipline, responsibility, speaking politely, caring, cooperation, selfconfidence.

\section{References}

Aprilia, B., Sari, Y. Y., \& Ghani, A. R. A. (2021). The Implementation of Cultivating Good Values Through Character Education in Prince's Primary School Tangerang. In 1st Annual International Conference on Natural and Social Science Education (ICNSSE 2020) (pp. 80-89). Atlantis Press.

Baguna, I. (2020). Implementation of Character Education: Impacts on Students and School Components at Madrasah Aliyah Negeri (MAN) Insan Cendekia Gorontalo. Journal of Asian Multicultural Research for Educational Study, 1(2), 26-30.

Baharun, H., \& Ummah, R. (2018). Strengthening students' character in akhlaq subject through problem based learning model. Tadris: Jurnal Keguruan Dan Ilmu Tarbiyah, 3(1), 21-30.

DeRoche, E. F., \& Williams, M. M. (2001). Educating hearts and minds: A comprehensive character education framework. Corwin Press.

Hasib, M., Nahruddin, Z., Tahir, M. M., Handam, M., Akbar, M. F., \& Nurdiansyah, W. (2017, November). Local Wisdom and Character Education in Youth Organizations--A Case Study of South Sulawesi Province, Indonesia. In International Conference on Administrative Science (ICAS 2017) (pp. 157-162). Atlantis Press.

Hulawa, D. E. (2018). Al-Zarnuji's Character Concept in Strengthening Character Education in Indonesia. Jurnal Pendidikan Islam UIN Sunan Gunung Djati, 4(2), 25-40. 
Jambak, A. (2017). Implementation of Character Values of Environmental Care in Geography Learning at SMA Negeri 1 Kinali. Sumatra Journal of Disaster, Geography and Geography Education, 1(2), 369-378.

Jamun, Y. M. (2018). Dampak teknologi terhadap pendidikan. Jurnal Pendidikan dan Kebudayaan Missio, 10(1), 48-52.

Magdalena, E., \& Notobroto, H. B. (2016). Pengaruh Aktivitas Seksual Pranikah, Ketaatan Beragama dan Sosial Ekonomi terhadap Kehamilan Remaja di Kecamatan Saptosari Gunungkidul. Jurnal Biometrika dan Kependudukan, 5(1), 19-26.

Nata, A. (2017). Edisi Revisi Akhlak Tasawuf dan Karakter Mulia.Jakarta: Rajawali Press

Pendidikan, T. P. I. (2007). Ilmu dan Aplikasi Pendidikan. Grasindo, Jakarta.

Saefullah. (2019). Manajemen Pendidikan Islam. Bandung: Pustaka Setia.

Satria, R., \& Shahbana, E. B. (2020). The SWOT Analysis of Strengthening Character Education in Junior High School. Jurnal Iqra': Kajian Ilmu Pendidikan, 5(2), 56-67.

Thompson, D., Etim, N. A. A., \& Etim, N. (2020). Environmental Management and Higher Education: Are they Closely Related? Journal La Edusci, 1(6), 15-24.

Wibowo, A. (2017). Manajemen pendidikan karakter di sekolah. Yogyakarta: Pustaka Pelajar.

\section{Copyrights}

Copyright for this article is retained by the author(s), with first publication rights granted to the journal.

This is an open-access article distributed under the terms and conditions of the Creative Commons Attribution license (http://creativecommons.org/licenses/by/4.0/). 